\title{
The Innovation Research of Ideological and Political Education in the Big Data Age
}

\author{
Rubing Dan \\ School of humanities, economics and law, \\ Northwestern Polytechnical University, Xi’an 710129, China \\ drb199023@163.com
}

\begin{abstract}
In the age of big data, the big data technology brings Innovation for the development of ideological and political education. The effective combination between the big data technology and ideological and political education is an urgent problem need to be solved. With distinct features and advantages of the age, the technology lays a good foundation for the ideological and political education. However, during the development, there still exist such tough problems as information security, negative information and imperfect facilities. In order to solve those problems and to achieve a new height of ideological and political education, it is necessary to make efforts firstly on conceptual updates, political support and self-development. The purpose of this article is to discuss some problems faced by the traditional ideological and political education when enjoying the advantages of the big data technology, and the solution of these problems.
\end{abstract}

Keywords-Big data age; Ideological and political education; Informatization; Innovation

\section{INTRODUCTION}

Ideological and political education means that a society or a social group uses ideological ideas, political views, and moral norms to impose targeted, planned, and organized influences on its members so that they form the ideological characters that conform to the needs of the society or a certain social class[1]. In the age of big data, this traditional definition needs to be reinterpreted by referring to features of the new era.

Big data, also known as huge amounts of data, refers to the fact that the data are so big that contemporary mainstream software tools are hardly able to capture, manage, process and deal with them in a short reasonable time and translate them into useful information to help social organizations with operating and decision making. It is fair to say that big data education is a heritage and development of traditional ideological and political education. Or we can say it's a powerful tool of ideological and political education.

With the advent of the era of big data, ideological and political education ushered in new opportunities for development. Compared with the traditional ideological and political education, the ideological and political education in the era of big data has many new characteristics and faces rare opportunities for its development. But at the same time, it is confronted with some serious problems. Hence, in order to better exploit big data and improve adaptability of ideological, those problems should be seriously dealt with.

\section{THE CHARACTERISTICS OF IDEOLOGICAL AND Political Education in the Big Data AgE}

\section{A. Huge amount of education information}

According to the monitoring statistics of International Data Corporation (IDC), the amount of global data in 2011 has reached $1.8 \mathrm{ZB}$ (1ZB equals to 1 trillion $\mathrm{GB}, 1.8 \mathrm{ZB}$ is equivalent to 1.8 billion mobile hard disks with a storage capacity of 1TB). Its value still doubles every two years. It is expected that by the end of 2020, we will see a total of 35ZB data globally.

These data are all-encompassing, including documents, pictures, audio, video, etc. They broaden ways for ideological and political educators to collect sample information. By using big data technology, real-time information of students' study and living conditions such as academic performance, attendance status, book borrowing situation, consumption of canteen card, Internet time, web browsing content, online social behavior can call be collected dynamically.

\section{B. Flexibility of educational modes}

The application of big data technology empowers ideological and political education to be more flexible, which helps realize personalized and preventative education. Traditional ideological education is rational. It tells students what they should do and why to do it. The education is usually lagged behind what actually has happened. However, since the core of big data is to make predication, educators could use data collection technologies and platforms to follow up dynamics of students and collect their data such as learning capacities, interests, personalities etc. and to make analysis and calculation so as to comprehensively understand the educated group, to scientifically predict possible problems and to take preventative measures. Most importantly, by using big data, it is possible to make reaction to uncertain events in advance and to more effectively grasp the development trend of ideological and political education.

\section{Quantification of educational methods}

In the big data age, data are not only the processing target, but are translated into basic resources. With the improvement of computer analysis technology and database, education can be studied in a quantitative way. Traditional ideological and political education tended to be emotional. However, big data 
affect the research and educational mode of traditional ideological and political education. Big data quantify students' information including emotional factors such as ideologies and emotion. Through terminals and Internet platform, we are able to collect students' ID swipe information, credit card consumption records, surveillance video, location, phone call, SMS, data traffic information if they use the mobile phone. By analyzing, calculating and integrating those data through technologies, it is able to comprehensively understand the ideologies, habits, preference and behavior of the educated target. Therefore, it is able to set targeted, customized educational goals, and implement relevant plans, strategies to improve the effectiveness of ideological and political education.

\section{The complexity of education careers}

Compared with traditional ideological and political education carrier, the carrier of big data ideological and political education is more complicated. Due to the rapid expansion of data size, the amount of data accumulated in various industries is growing and their types are increasingly diverse and complicated. It is not easy to distinguish good information from the bad, and they are constantly developing and changing. "Admittedly, it is a complex project for educators to fully take advantages of big data carriers and to find useful and relevant information in the midst of dynamic data stream. Therefore, it requires us to make breakthrough and overcome difficulties in analytical awareness, competence and technologies.”[2]

\section{CHANGES OF IDEOLOGICAL AND POLITICAL EDUCATION IN BIG DATA AGE}

\section{A. Innovation of educational ideas}

The dominant feature of big data era is datamation. For hundreds of years, Chinese people tend to think in a cause-andeffect way and believe causes lead to effect. Big data can only explain what it is. If we aim to solve "why it is", ideological and political education is the necessary tool, which is mean to help people set correct world outlook, outlook on life, and values.

Big data has changed the way people perceive the world. In the past, there are only a few angles for people to make observation. However, today, massive information allows people to solve the problem of "what it is" through various perspectives. Hence, it also needs innovation to solve problems of why it is. Put it in another way, in the age of big data, students are not only expected to explore cause-and-effect relationship but are encouraged to explore mutual relations between things. This thinking method would bring new ideas for institutes of higher learning to innovate ideological and political education.

\section{B. Richness of educational resources}

One of the basic characteristics of the big data age is the massive quantity of data. With the development of the Internet, the amount of Internet data has been growing rapidly. Those data provide institutes of higher learning with rich educational resources. The unprecedented data has completely subverted data transmission methods in previous paper media age; Big data age features diverse data formats, with both printed information resources and video, images, text exclusive in this age. Hence, ideological and political education should seize this opportunity to change the traditional teaching mode.

\section{Anticipation of education contents}

Big data has brought great convenience to our lives, prominently featuring its data analysis to predict human's behavior. Therefore, it is completely feasible to establish an early warning mechanism over the thoughts and behaviors of college students. Usually, the mental states of students within a certain periods can be learned by collecting their online messages, comments or upgrades from their accounts of Wechat or Microblog. Then judgments of their thoughts acts and intentions can be obtained. For example, students tend to seek comforts or help by sharing their feelings caused by exam failures, emotional problems or interpersonal difficulties on the internet. The big data technology provides college psychological counselors with easy access to timely information of their drastic mental fluctuations and possible reasons. The psychological professionals can accordingly give the sufferers more care and guidance that can help the out. Consequently, potential incidents get effectively avoided.

\section{Reasonable educational administration}

The efficient data acquisition, storage and analysis make the big data increasingly a new approach for people to decide and predict which contributes to the reasonable and standardized administration of college ideological and political education, making it more targeted and effective. Due to the facts of large student population and insufficient education resources, immediate solutions are demanded to transform the limited resources into quality services for students. Conventionally speaking, the teachers' vigor is limited, so it is impossible for the benefits of mental assistance to reach every student. The negligence is truly unavoidable. Fortunately, the big data guarantees the education practitioner with more comprehensive information of each student's minds by extensively collecting and in-depth digging the data.

\section{The Problems FACING THE IDEOLOGICAL AND POLITICAl EdUCATION IN THE ERA OF Big DATA}

\section{A. The incompatibility of ideological and political education and big data}

The analyzing and managing process of big data is a highly professionalized skill, which requires a combination of expertise from multiple fields, ranging from math and statistics to computer science. While its application in ideological and political education refers to a multidisciplinary collaboration among data digging and screening, quantitative and qualitative analysis, software assistance and mental education. In fact, most researchers specialized in mental education are incapable of using the technology for mental analysis since they are illequipped with the above skills. However, researchers with data processing abilities also lack knowledge into ideological and political education. 
Additionally, it is difficult to combine the two in a proper manner. Since the ideological and political education basically targets human that have minds and feelings, we cannot rely too much on quantitative analysis of data. It is an irreversible trend that the big data will merge with ideological and political education. Yet, if people hold the blind faith of "data decides all” as the golden role, the mental education will suffer.

\section{B. The negative information that is hardly avoidable}

The massive contents from big data offer quality resources that can benefit education. Yet there are also negative ones, although for a small share. How to obstruct the negative and profit the students becomes a headache facing the ideological and political education in the big data age.

The negative informative fills the internet and influences students' acts and thoughts. For instance, our country is encountering multiple social problems, such as territorial disputes, income disparity, and issues concerning education, medical care, social insurance and religion, even some violence. Some are normal and can be solved via proper approaches, while the others are sometimes distorted to provoke the public, and the situation gets exacerbated. Peaceful settlement over territorial disputes is misinterpreted as government cowardice, income disparity as "hatred against the rich". The incomplete system of social insurance are unreasonably compared with the ones in developed world, ethnic and religious issues often fuels flame wars among netizens and violence is imitated by other criminals. To conclude, ideological and political education must stay away from big data if the negative information remains.

\section{Students' privacy safety cannot be guaranteed.}

In the era of big data, students are encouraged to learn new knowledge via the internet. The diversified development of innovative mental education also profit from big data. Accordingly, the safety of students' privacy demands an urgent solution.

On one hand, the universal application of big data may cause the students' privacy to be exposed on the internet. When they search, shop or socialize with their friends, the browser will learn what they want and give advertising messages. The shopping website can identify their names, phone numbers, home addresses and shopping preferences through the goods they have gone through. Social websites can recognize their education information. The locating function of cell phones will expose their location. Information management system in colleges carries detailed privacy of students while with relatively weak security. On the other hand, big data also enable social phenomenon analysis and future predictions. Whether one can collect and publicize the information is still under discussion.

\section{Supportive measures do not work well with it.}

Considering the constantly-changing characteristic of big data, supportive measures are required to utilize the technology more efficiently for ideological and political education, such as improved education philosophy and approaches, upgraded educational facilities and faculties. However, the "hardware condition" of data faithfulness and rationality cannot be effectively ensured, let alone the "software condition". China's conventional education approach is famous for its feature that teaches by words and influence by deeds. Similarly, the conventional methods of ideological and political education even focus more on teaching via guidance; they are expecting virtuous mental improvements among students. Currently, mental educators are mostly college teachers or instructors. Their experience has been summarized into a rigid teaching approach with individual characteristics which hinders big data consciousness to progress and the technology to generate profits.

\section{CONClusion}

In the age of big data, ideological and political education is confronted with many complex problems. How to properly react to the changes and solve the problems determines the successful transformation of ideological and political education. Based on the issues mentioned above, the following aspects shall be considered.

\section{A. Open minds and renewed thoughts}

School ideological and political counselors are encouraged to establish a big-data-think-mode with open minds and renewed thoughts. Students grow as the info-technology develops, which helps them form great reliance on information and data. In the face of problems, students take the computers or cell phones as their first choice to seek help, while the grown-up educators are much poorer at using the technology. If metal education want break the bottleneck with big data, school counselors must change their minds and think-mod, and face the challenge proactively to improve their analytical skills and application capacities. Meanwhile, some informationzed contents should be added into the conventional mental education and the knowledge structures should also be upgraded.

Education workers need to improve their ability to identify the positive information among the massive data where much negative ones hide. As a result, the student can obtain positive energy and steer clear of the distorted information that will harm their values. For the educators, the quantity of data can never guarantee data's reliability; reliable data is only accessible with a clear idea of cause-effect relationship. Only by improving their analytical abilities and professional standards can they effectively verify the source, quality and analysis results of data and improve the data credibility.

\section{B. Policy and legal guarantee for information security}

A security and emergency platform should be established for data. On one hand, it can monitor departments in charge of data-collecting, data-storing, data-analyzing and data users, and urge education workers to collect and use the data in a lawful, reasonable, safe and effective manner. On the other hand, defensive barrier should be built to protect the data from hackers' attack and avoid information leakage. Once the data is found to be leaked, a destructive interceptor will be quickly initiated to destroy the information when it spreads. Consequently, the harm to the privacy-holders get minimized. 
In order to protect privacy, an accountability mechanism should be introduced as a policy guarantee for the data security. Education workers take full responsibility for the source, usage, and security of data. The rules and regulations for data usage can help to assess the risks. Once infringement takes place, the responsible party can be identified effectively. Additionally, there should be some legal measures to safeguard the data security.

\section{Enhancement of support and service for ideological and political education}

The quantitative feature of big data usually misleads the public to treat the technology as a tool. In fact, ideological and political education focuses on human natures, instead of tools. The reasonable usage of big data can enhance human's understanding of themselves and the world. "Big data is far more than a online-tool for mental education, it provides the students with a lot of spaces and possibilities for rational thinking."[3]

Currently, the internet is increasingly aware of what people want. When people are using the internet, the most frequentlyreceived messages are about those that have been searched recently or the users are interested in. the same reason can be applied to mental education. Based on the data analysis over the borrowing or clicking percentage in the (e-) library or the downloading, clicking or spreading percentage of current affairs by the students, judgments can be made to identify their interests, questions and what is most useful to them. And textbooks, course design and practices can be adjusted accordingly. Moreover, education workers can personalized allocation of resources by combining the ancient classics, scientific theories, current affairs, comments and remarks, or by integrating politics education, moral education, ethics education and psychological education together.

In a word, the ideological and political education has already been on the journey of transforming itself among massive data resources. If innovation is expected in mental education fields, it must proactively collaborate with the big data, during which problems can be exposed and solved.

\section{REFERENCES}

[1] W.B. Chen and Y.C. Zhang, "Principle of Ideological and Political Education,” Beijing: High Education Press, 2007.(references)

[2] Z.X. Hu and J. Yu, "Research of Ideological and Political Education Carrier and Strategy in Big Data," Studies in Ideological Education, Vol. 247, pp. 74-77, February 2015.(references)

[3] H. Jiang, "The Challenge for the Ideological and Political Education and Response in the New Media Era,” Ideological and Political Education Research, Vol. 31, pp. 123-126, June 2015.(references)

[4] C.L.Ma, "The Opportunities and Measures of College Students' Ideological and Political Education in the Internet Age” Journal of Educational Institute of Jilin Province, Vol. 31, pp. 38-39, August 2015.

[5] Y.N. Zhang and Z.J. Zhao, "Reflections on Inspiration for Education from Thinking Mode in Big Data Age,” Education development research, Vol. 21, pp. 1-5, 2013.

[6] X.L. Zhou, "Education Management Reform in the Era of Big Data," Chinese Education Journal, pp. 25-30, October 2014.

[7] Q.Z. Qiu and P. Sun, "Opportunity and Challenge of the Ideological and Political Education in Universities in the Age of Big Data,” Theory and Practice of Education, Vol. 36, pp. 35-37, 2016. 